\title{
If You Build It Will They Come? Using a New Library Building to Establish a Culture of Marketing
}

\author{
Karen Brodsky
}

SUMMARY. While most college campuses have strong support for the libraries, as competition on university campuses for limited financial resources gets tougher, support for libraries can be more theoretical than actual. Library users are unaware of the complexity of and expense required for library services. Not only must libraries compete for limited financial resources, they must also compete in a complex information marketplace. Today, libraries must market themselves to their constituents to ensure that services are utilized and appropriate resources are allocated for all formats of library materials. By committing to a strong marketing program, the University Library at Sonoma State University developed strategic plans to gain broader support from faculty, students, administrators and greater use of services. Libraries wishing to explore the possibility of integrating marketing efforts or libraries in the process of a move can adopt and/or adapt some of these techniques. [Article copies available for a fee from The Haworth Document Delivery Service: 1-800-HAWORTH. E-mail address: <docdelivery@haworthpress.com> Website: <http://www.HaworthPress.com> () 2003 by The Haworth Press, Inc. All rights reserved.]

Karen Brodsky is Senior Assistant Librarian, University Library, Sonoma State University, 1801 East Cotati Avenue, Rohnert Park, CA 94928 (E-mail: karen. brodsky@sonoma.edu).

[Haworth co-indexing entry note]: "If You Build It Will They Come? Using a New Library Building to Establish a Culture of Marketing." Brodsky, Karen. Co-published simultaneously in The Reference Librarian (The Haworth Information Press, an imprint of The Haworth Press, Inc.) No. 82, 2003, pp. 183-197; and: Outreach Services in Academic and Special Libraries (ed: Paul Kelsey, and Sigrid Kelsey) The Haworth Information Press, an imprint of The Haworth Press, Inc., 2003, pp. 183-197. Single or multiple copies of this article are available for a fee from The Haworth Document Delivery Service [1-800-HAWORTH, 9:00 a.m. - 5:00 p.m. (EST). E-mail address: docdelivery @ haworthpress.com].

http://www.haworthpress.com/store/product.asp?sku=J120

(C) 2003 by The Haworth Press, Inc. All rights reserved.

Digital Object Identifier: 10.1300/J120v39n82_12 
KEYWORDS. Marketing, public relations, outreach, new building projects, building projects

I once asked an administrator on my campus for advice about how the library could gain more resources and support for information competence initiatives. Her response was: "Of course there is support for the library, the library is like mom and apple pie." In essence, she was telling me that libraries epitomize the notion of a democratic society and, in theory, there is great support for what we do. Well, of course people support libraries! Libraries are the storehouse of information. They are the great equalizer by providing access to the world's recorded knowledge. People working in libraries are there for the sole purpose of assisting others in their pursuit of knowledge, with no judgment. Librarians, and others who work in libraries, facilitate the discovery of information and the wonder of learning. How could anyone NOT support the notion of libraries and librarians; and, in this day and age, it is easy to argue that libraries are more important than ever. Our society is inundated with information daily (some of it cited, some of it not). The Web has made so much information more easily accessible than ever before in history. A librarian's ability to assist people in weeding through the morass of information in order to make informed, intelligent decisions is more crucial than ever. However, with a lack of resources in most academic institutions, and the exponentially rising costs of running a library, support can often be only of the philosophical kind. Many library budgets have remained flat (or worse, decreased) over the past several years, while operational costs have risen.

Further, students constantly tell us they prefer using the Web because it is easier and more convenient than using complex library resources; and of course, as many students might say, everything they would ever need is available on the Web anyway. According to the recent Pew Internet and American Life Project "nearly three quarters (73\%) of college students say they use the Internet more than the library, while only $9 \%$ said they use the library more than the Internet for information searching."

In addition to the changing information environment, the information marketplace has changed. In the past, libraries did not have to compete with such information services as Google and Amazon.com. A library could simply send out a flier or newsletter about upcoming activities or changes in a collection because users were very limited in where they could go to find information. Ellen Dodsworth states "it is easy for an academic library to become complacent because it has no natural information competitors on campus to stimulate the business instincts to market within an institutional structure" (320). This is not the case today. If libraries believe they have a valuable product, it is essential for them to compete. Libraries can learn from Theodore Levitt's heavily cited 
article "Marketing Myopia (With Retrospective Commentary)" in which he states, "There are only companies organized and operated to create and capitalize on growth opportunities. Industries that assume themselves to be riding some automatic growth escalator invariably descend into stagnation" (30). Of the four conditions Levitt claims can lead a company into a downward spiral, the one that resonates most directly for libraries is "The belief that there is no competitive substitute for the industry's major product" (30).

It is easy for people in this evolving profession to bemoan a lack of understanding and actual support by administrators and faculty of what we do and what it takes to operate a library, and it is easy to "tsk tsk" the students who "are less aware of a pre-Internet world than they are of one in which the Net is central to their communication" (Pew). However, it can be argued that a lack of marketing naturally causes users to not know about the rich offerings of libraries. It is astounding that librarians of all ranks continue to belittle the need for marketing. While librarians' understanding of and commitment to marketing is changing, some in this profession believe it is the users' responsibility to find out about the challenges we face, the complexity and costs of the services we provide, and that it is NOT our responsibility to tell them what we do. Some librarians are of the opinion that resources are too precious to be spent on marketing initiatives like newsletters. Ironically, this logic actually contradicts what it means to be a librarian; that is, it is our professional responsibility to assist people in their pursuits of becoming more informed-so why not help them become more informed about libraries by committing to marketing initiatives?

Throughout the literature, there are pleas for libraries to move marketing efforts from the philosophical to the tangible. As recently as November 2002, articles in library journals continue to impress upon librarians the need to promote library benefits to their campus. W. Lee Hisle writes:

We must find ways to promote the values, expertise, and leadership of the profession throughout the campus to ensure appreciation for the roles librarians do and can play. Though access to information is increasingly decentralized, and computer labs now compete with libraries as campus gathering points, librarians must demonstrate to the campus community that the library remains central to academic effort. (715)

E. L. Morgan states, "There are many more people and institutions providing information services today than even five years ago ... We have to do more to improve our services and convince people that they should use libraries instead of other information providers" (qtd. in Jackson 50). Anne Lipow declares, "If we don't act, we will not only witness the disappearance of reference service by librarians but will also see commercial interests like Microsoft step 
in and fill the vacuum, furthering the privatization of library functions" (50). Rudi Denham says:

In the past 10 years there have been tremendous changes in society that affect the entire concept of what a library is and does. Libraries are under threat. They face critical issues that threaten their very existence. The same issues face all types of libraries: university, research, public, school, and special. Libraries face increased cost and expansion in the variety of materials. They face increased competition and the impact of new technologies. But these threats may also be challenges. They give libraries the opportunity to redesign their own future. (qtd. in Dodsworth 320)

However, some librarians are responding to the call of their colleagues. Maureen Jackson states, "In an increasingly competitive world, Library and Information Services have come to realize that they too must promote and publicize the services and products they offer" (43).

Developing an effective culture of marketing to stay competitive is often the biggest challenge. The marketing program of the University Library at Sonoma State University was a proactive response developed to reposition the library from what had been a small and rather traditional academic library into a lively, energetic, rejuvenated, and welcoming resource for the entire community. By committing to a strong marketing program, the University Library was able to develop strategic plans in order to gain broader support from faculty, students, administrators, and greater use of services. Libraries examining the possibility of integrating marketing efforts or libraries in the process of a move can adopt and/or adapt some of these techniques.

For the University Library at Sonoma State University (SSU), a new building afforded a unique opportunity to begin a marketing program enabling us to examine the role of the library on the campus and in the community, as well as incorporate marketing activities into daily operations, thus developing a culture of marketing.

\section{THE SETTING AND THE IMPETUS}

SSU is a public liberal arts institution, one of twenty-three campuses in the California State University system, approximately one hour north of San Francisco. Established in 1961, SSU grew up during the free-spirited and turbulent '60s and '70s. Staff and faculty, many still employed at the university, came from the radical Bay Area during those early years, looking for a place where the true expression of ideas could flourish. In the rural tranquility of Sonoma County, a unique sense of community developed. The library was part of this 
charming family, doing what libraries did in those days-building and managing collections in order to help whomever came through the door. Throughout the years, the library sent occasional fliers informing the campus of various services. As the years moved forward, the university maintained its small size while remaining largely isolated from the larger community.

During the early 1990s, campus budget cuts forced the library to drastically reduce periodical holdings. Many faculty have never recovered their faith in the library; they are unaware that many titles were reinstated later either in print or electronically. At approximately the same time, a bond measure was passed to build a new university library. This new facility was to be truly cutting edge, not a typical library. In fact, much to the chagrin of many on campus, it was to be called an information center, not a library. One of the cutting edge features was to be an Automated Storage and Retrieval System in which books and bound periodicals could be stored and quickly retrieved via requests from the online cata$\log$. Because some items would be in storage, more space would be available for group study, computers, and other developing student needs. There was such negative reaction from faculty about the concept of storing library items, i.e., not having materials on the open shelves, the library management decided to drop the term "Storage" and call it the Automated Retrieval System (ARS).

As the initial plans for the new building were developing, society entered the information age, and the electronic era took control of libraries. The world of information was changing, and libraries had to change with it. Also during this time, the local environment of Sonoma County was changing. People began moving to the area in record numbers in order to avoid rising housing costs in San Francisco and Berkeley, the telecommunications industry moved to the area with fervor, and the wine industry became as strong a voice as traditional Sonoma County agricultural products such as apples and poultry.

An interim dean took over in 1999, just as the final phases of planning and construction began for what was to be the Jean and Charles Schulz Information Center, named after the famed Peanuts cartoonist. Under the direction of this new dean and with the support of the library faculty, a commitment to undertaking marketing initiatives was agreed upon despite limited resources and strong resistance from some in the library. An extensive marketing/public relations campaign was developed to inform the campus about the new building, any moving plans that would impact library services, library services in general, and to dispel some of the rumors that had been circulating for years, such as the library has no current materials, and the new library would have closed stacks.

\section{DEVELOPING THE PLAN: ASSESSING STRENGTHS AND WEAKNESSES}

In developing marketing efforts, the library adhered to such standard marketing principles as assessing strengths and weaknesses and clearly identifying 
clientele. To begin, the library faculty and dean had many discussions examining the patron base, goals for the library, and the library's resources. It was not always easy to honestly look at strengths and weaknesses in an open collegial exchange. A facilitator was hired to help to ensure discussions were productive. It was clear to all that many obstacles were ahead-the new building was surrounded by great controversy because of the ARS and the name, for example. Further obstacles included a growing traditional-aged student population, a newly integrated library system, enormous misunderstandings about library resources and services, and developing plans for working in a new building twice as large with the same number of staff.

Through these discussions, it was agreed upon that educating the entire SSU community about the library's vital role should be the ultimate marketing goal. Specific issues related to the new building also needed to be addressed, and through honest dialogue, the group realized we also wanted to change the image of the library, use of the library, and support for the library. Truly becoming "student-centered" and being perceived as such was another agreedupon goal. Yet another goal was for the library to become a cultural hub for the campus where all members of the community could come together to share and discover ideas. While we knew that a shiny new building would do much to help our image, there was no denying the new building offered us a limited opportunity to reposition the library on campus-both academically and politically.

A good marketing plan addresses external and internal customers. It was important to educate not only our users about the library, but to educate library employees about the need for marketing. Initially, it was difficult to get many of the library staff to understand the importance of pursuing marketing efforts. Because marketing seemed to be a four-letter word, the dean termed our marketing initiatives "outreach," thus initiating the Outreach Program, with a librarian put in charge. On the surface, some people seemed to understand the importance of outreach activities, but behind the scenes, there was not unanimous support. Often people appeared to support marketing initiatives, but did not think about marketing when planning new services or developing informational tools. It is easy to understand the apprehension and ambivalence about marketing-people fear the impact from an increased use of services; there can be a fear of loss of control, autonomy and, in an academic environment, loss of what can inaccurately be labeled academic freedom. In the University Library, the process of educating library employees about the need for marketing began with discussions in department meetings and special library-wide meetings on a variety of marketing topics. Often guest speakers were invited to librarywide meetings to discuss changing SSU demographics, student expectations, changing campus initiatives, and other topics that impact marketing decisions. 
All library employees were encouraged to participate in marketing initiatives, share ideas, and provide feedback.

\section{DEVELOPING THE PLAN: A MARKET ANALYSIS}

Through many discussions, the library faculty and dean looked very closely at whom we served and what services they needed. SSU is an undergraduate liberal arts institution with changing student demographics and a substantially increasing residential population. There was an increase of newly hired faculty, as many of the original faculty retired, thus a changing curriculum. In addition to SSU students, faculty, and staff users, commitments for service in the new building had been made to the local school district. And, the University has spent the past few years reaching out to the greater community. User needs were also changing throughout the library world, as an early survey conducted by the Digital Library Federation finds: "84 percent of survey respondents indicated that the Internet had changed the way they use their own institution's library" (Greenstein and Healy 16). It was clear that not only were patron demographics changing since SSU's inception, but user needs were changing as well.

\section{DEVELOPING THE PLAN: RESOURCES NEEDED}

Once the library better understood who our users were becoming and how our services would need to change to better meet these users' needs, the library dean and library faculty looked at available resources for marketing. In order to develop a culture of marketing that would thrive beyond the move, the largest resource allocation would need to be staff time. The library did not have a history of marketing in a professional manner, nor had staff time ever been dedicated to marketing efforts. It was agreed that $50 \%$ of a librarian's time was to be allocated to directing a marketing program. Because marketing initiatives were to be more strategic than simply creating a few brochures or a newsletter, success would be dependent on someone having time to develop a program. Initially, student assistant time was also allocated to marketing efforts. The library's financial resources were extremely limited, thus innovation was essential to achieving marketing goals inexpensively and/or collaboratively with other units on campus or members of the community.

\section{THE MARKETING MISSION}

With a general sense of direction, planning the outreach program began by adopting a marketing mission statement: 
The mission of the University Library's Outreach Program is to provide the Sonoma State University community with the knowledge that the Jean and Charles Schulz Information Center is the county's most vital resource for the discovery of information. We strive to promote the unique features and services available in the Jean and Charles Schulz Information Center by integrating the library, whenever possible, into the larger campus and local community. (Brodsky)

The goals for the program were twofold. First, we wanted to inform library users, especially students, of services and resources available. Second, we wished to garner the greatest support for library activities and initiatives on campus and in the community. Marketing efforts were designed to present an integrated, unified image of the library, in which each department's unique aspects combined to create a cohesive, student-centered organization. There was a constant need to combat the negative impressions of the library on campus and in the community, especially towards collections. Initially, it was also imperative to address a multitude of concerns surrounding the new facility.

\section{THE PROMOTIONAL CAMPAIGNS}

Two campaigns were developed, one to inform users of library services, and one to inform users about the new building. The strategy reasoned that by instituting a marketing plan for the new building, a culture of marketing would develop within the library to ensure future outreach efforts. Following is a brief description of the two campaigns.

\section{Your University Library Campaign}

As previously stated, this campaign was designed to inform the campus about library services and resources. Beginning in 1999, the marketing department systematically began highlighting services and collections using a variety of venues (the weekly campus newsletter, an internal library digest, the student newspaper, the library website, residence halls newsletter, and other appropriate venues). The "News from the Reference Desk" flier distributed each new semester was changed to "News from the University Library" in order to present a cohesive message from a seemingly unified organization. A "New Book" display was added in the main lobby, intended to combat the impression that new materials were not added to the collection. This was more difficult than expected; some in the library believed the display would be a disservice, because patrons would need to look in several locations for materials. After much discussion, it was agreed that having a new book display was an important service to patrons. This is now a favorite browsing area for patrons. A lively display, "50 Things You Can Do in YOUR Library," was created for the main lobby with a corresponding link on the website. Everyone in the library was asked to participate and 
submit ideas, generating a great deal of fun for those who participated. It is currently updated once or twice a year and is available at $<\mathrm{http}: / /$ libweb.sonoma. edu/about/50things.html>.

\section{The Jean and Charles Schulz Information Center Campaign}

Simultaneous to the "Your University Library" campaign, an exhaustive PR campaign began ten months prior to the move date. This campaign, which targeted the campus, was broken into three components:

1. Not Business as Usual-conducted prior to the move. The goal was to keep the campus informed of "move-related" issues and to educate patrons about features of the new building. An information campaign, titled "Library Move Alerts," disseminated timely updates through various venues such as the weekly campus newsletter, memos signed by the library dean and distributed to all employees, an easily accessible link from the library home page, an e-mail list, a bulletin board in the library lobby, "town hall" meetings, outgoing messages on all of the library public phones, and regular visits to all campus departments.

Developing a graphic identity and graphic standards for the new facility was also necessary. This involved a new name, a logo for all letterheads, business cards, brochures, and a new web site. In so doing, the marketing coordinator worked closely with the Development Office, the President's Office, and the University Affairs Office. Aesthetic principles and standards were developed for maintaining the interior of the new facility. For example, templates were designed for signage, especially temporary signage, such as when the copiers were out of order.

2. We're Moving-conducted during the move. The library was closed only three weeks for moving from the old building to the new one. During this time, the University Affairs Office provided the marketing coordinator with an office to answer patrons' questions and field press queries. Temporary signs were posted across campus warning people of the moving trucks, and temporary signage was placed on both buildings informing people of the anticipated opening date, the first day of classes for the Fall 2000 semester.

3. Some Services Might Not Be Fully Operational-conducted after the move. While it only took three weeks to move and unpack the collection, the library was not fully operational on opening day. It was important to inform library users of the phase-in plan. To aid in this, the VP for Academic Affairs included information, supplied by the library dean, in his convocation speech, informing faculty and staff that the library would be open but not fully operational on the first day of classes. Most users were quite sympathetic to the "unpacking," and the library was able to bring services up fairly quickly. To inform users when services were fully operational, communication venues established before the move (campus newspapers, e-mail, and the library web site, to name a few) were again used. In addition, a variety of dedication events throughout the first year and a half aimed to bring people into the library and 
inform them of services and collections. Dedication events included a grand dedication, featuring students from the theater department singing songs from "You're A Good Man Charlie Brown," an appearance by Snoopy, and a special poem written for the library by the Sonoma County Poet Laureate.

The library also co-hosted a unique, mid-semester party with the Alumni Association titled "A Cook's Tour of the Information Center." Using recipes from a famed local chef's recently released book, A Cook's Tour of Sonoma County, guests had the opportunity to visit all three floors of the library while sampling different foods from the cookbook in each area. Dedication events were also held for the clock tower and carillon, a unique room built for the gift of a Jack London collection, and an outside plaza area named for one of the founders of the university.

\section{NO LONGER THE NEW KID ON THE BLOCK: A RETURN TO PROMOTING SERVICES AND COLLECTIONS}

The library was aware that at some point the novelty of the new building would wear off, and the work of simply marketing library services and resources would begin. After the first year in the Jean and Charles Schulz Information Center, marketing efforts began to shift. Rather than focusing on the building, the efforts concentrated on informing users about library services, promoting the image of the library as student-centered, and gaining political support for library initiatives.

One of the visions for the new library building was to be a campus cultural center, or as our president refers to the library, the campus living room (to this end, we allow food and drink in the building). Thus, a variety of activities were developed as part of the Jean and Charles Schulz Information Center, all directly relating to the marketing goals. What follows is a brief list of some of the ongoing outreach activities. While each activity has a variety of unique goals, the common denominator is the intention to bring people into the building, with the assumption that once inside, they will become aware of other services.

\section{Murder in the Stack}

As a part of the campus Welcome Week activities, the library collaborates with other campus entities, such as the Residential Life Office and the Alumni Association, to create "Murder in the Stacks." A fun, educational event, "Murder in the Stacks" introduces incoming freshmen (although any student can attend) to the University Library's many features and services. Professional actor "suspects," hired through a murder mystery theater company, are stationed at various locations throughout the library, providing clues while highlighting library features and services. Teams of students explore the building, questioning the suspects and gathering clues to solve the murder mystery, as well as unlocking the mysteries of the library. This event is held the Friday before La- 
bor Day (for students who stay on campus that weekend) and has a lively, party atmosphere with a dj, dancing, and food. The first year, over eighty students attended; the second over 200. The University is committed to continuing this successful program. More details about it are found at http://libweb.sonoma. edu/whatsnew/murder/index.htm.

\section{Arts and Lectures Program}

The design of the new facility provided space for hosting a variety of cultural activities. The Arts and Lectures Program in the University Library strives to enrich the intellectual, educational, and cultural life of the Sonoma State community. The program provides a venue for people to come together to share ideas through art, lectures, and discussions. Activities are designed to explore a diversity of ideas, values, and intellectual and artistic expressions. Emphasis is placed on exposure to library collections, research interests of SSU faculty, staff, and students, and regional issues including the support of local cultural initiatives. The program consists of an art gallery, which is approximately 1,200 square feet, a beautiful meeting room for hosting lectures and discussions that can accommodate nearly 100 people, and display cases positioned throughout the building. The Arts and Lectures Program is designed to host five exhibits per year, two of which exhibit student work or are student-curated; the fall semester lecture series is centered on a theme and the spring lecture series highlights faculty and student research and interests. This program, while coordinated through the library, is becoming a campus-wide collaborative endeavor. Faculty and students present ideas for lecture series and art exhibits. Long-established campus lecture series have begun looking to this program as a resource. During the first two years of this program, the University Library hosted eleven art exhibits, over 5,000 people attended a lecture or reading, and twenty displays highlighting library collections were created.

\section{Schulz Unplugged}

Premiering in the fall 2002 semester, this unique program brings live music into the library on Friday afternoons for one hour. Held in the multimedia area, Schulz Unplugged was developed to address the needs of a growing residential campus by furthering the role of the library as an activity center for the campus.

\section{New Faculty Lunch}

As a way to introduce the library and library faculty to new instructional faculty, an annual New Faculty Lunch takes place during the spring semester. During the lunch, sponsored by the Friends of the University Library, new faculty are provided with a library handbook, questions are answered about the collections, the librarians inform them of the instructional programs, and offer 
suggestions on how librarians can be important partners in meeting curricular goals, such as consulting in the development of library-related assignments.

\section{Newsletter}

The 2002/2003 academic year began with the first issue of the library newsletter-Access. This newsletter targets supporters and potential supporters (administrators, faculty, donors, and potential donors). The editorial content informs readers of services and collections (new and ongoing) and provides a glimpse into the intricacies of an academic library in this day and age.

\section{Presentations}

Information about the library is presented at every opportunity possible, such as the new and transfer student orientations, Life Long Learning orientations (a university program for the "over 50 crowd"), and parents weekend. Tours are provided to whomever may request one-from visiting librarians planning their own new facility, to retirement community members wanting an afternoon outing, to VIPs visiting the campus, to grade school students.

\section{One-Time Events}

Opportunities often present themselves for one-time "events," usually focusing on a new resource or change in a database system. For example, when eBooks were added to the library collection, an "eBook Signing (Up) Party" provided faculty the hands-on opportunity to learn about this new resource. While the turnout for this particular event was small, every faculty member on campus received information about the eBook collection through both print and electronic invitations. Publicity also appeared in the campus newsletter and a request was sent to all deans asking them to encourage faculty to attend.

\section{Community Events}

Whenever possible, the University Library participates in appropriate community events such as the annual Sonoma County Book Fair and the Sonoma County Reads project.

\section{GETTING THE WORD OUT AND HOW IT LOOKS}

Disseminating Information-Informing clientele of services available is one of the foundations of any marketing campaign. The library continues to use all possible avenues to disseminate information. Regular campus mailings occur to faculty, staff, residence halls, and student clubs, informing them of new services. These mailings consist of over 3,000 fliers distributed to all campus mailboxes. This requires a good relationship with campus mail services to ensure updated lists. Press releases are sent to campus newsletters, the student newspaper, residence hall newsletters, community newsletters, and all media venues in Sonoma County, large and small. A variety of e-mail lists have been 
created for weekly updates such as readings/lectures for the coming week. The librarians continue to regularly visit schools and departments at least once a semester, and liaison activities have taken on greater meaning. The library "tables" at campus and community fairs, and the library faculty and dean are actively involved with campus initiatives and regularly attend campus meetings, events, and participate on committees.

Materials-Another important marketing principle is the concept of brand identity, which is taken very seriously at the University Library. Every information item created for dissemination to the public includes the library name and $\operatorname{logo}$ (or a variation if space is an issue). Those in the library who understand the need for marketing have come to realize that the library web site is not only an important tool for accessing information, it is one of the most important marketing tools; thus resources are put into assessing the usability of the site. The web site is also heavily used to promote library activities, events, and initiatives. All informational and instructional handouts, orientation materials, and temporary signs have a standardized format making it easy for people to identify materials from the University Library. Even the handouts the librarians create for one-shot sessions include the library name and logo.

\section{FRIENDS AND PARTNERS}

Part of the success of the library's marketing program is due to the partnerships developed. Because of the implications of the new building for the University, exceptional working relationships were forged with the University Affairs Office and the President's Office. The dean and the marketing coordinator worked closely with the Development Office in finalizing building details such as donor plaques and dedication events. Through the library's ongoing commitment to students, close working relationships have developed with the residence halls, dining services, and other student focused organizations. Through the Arts and Lectures program, strong working relationships with departments on campus such as the art and theater department now exist. Finally, one of the most unique collaborations has been with the Alumni Office. The library is able to organize, promote and host lectures by the Distinguished Alumni as well as highlight the achievements of these individuals through displays in the building. The Alumni Association, in turn, is often one of the first organizations to support library initiatives with financial resources such as co-sponsoring "Murder in the Stacks."

\section{WHAT IT TAKES}

Developing a marketing program requires first and foremost a strong commitment from the library dean. Without leadership from the top, it would have been very difficult to successfully undertake most of these initiatives. Follow- 
ing the dedication of the dean is support of the other librarians and staff. While not everyone was on board from the start, critical mass has developed over time in support of marketing.

Marketing is a constant balance of opportunities and challenges. It is important to understand that marketing opportunities exist everywhere; it is simply a matter of seeking them out and realizing that ideas come from anywhere. Looking at everything as an opportunity implies the need for ingenuity-in imagining what can be accomplished and in learning how to get projects completed. Some things work magnificently the first time and fail miserably the second time. It is important to have patience and remain optimistic.

The costs for maintaining a marketing program can vary as widely as the variety of academic libraries. For the program at the University Library at SSU, $50 \%$ of a librarian's time is now dedicated to outreach initiatives. When the program began, student assistants provided help. The student hours have since been replaced by $50 \%$ of a staff person's time. This library was fortunate to have in-house design capabilities and through the many relationships developed on campus, campus "friends" often provide assistance. Most printing is done in-house with copy machines on quality paper. There is not a line item in the library budget for any of these activities; financial support comes from the Friends of the University Library, the Alumni Association, partnering with other campus entities, and others.

\section{CONCLUSION: SUCCESS OR FAILURE}

Have we meet our goals of (1) informing library users, especially students, of services and resources available; and (2) garnering the support for library activities and initiatives on campus and in the community? In assessing this program over the past two and a half years, there have been both successes and failures. Students feel comfortable in the library building, visit librarian office hours, ask questions at the reference desk, use various services in ways not seen prior to the move or since instituting an outreach program. Building use statistics have increased by $40 \%$. While some of the increase is easily attributed to a beautiful new facility, two and a half years after opening, with ongoing outreach activities, these statistics continue to increase. The library now presents a cohesive, unified organization to the entire campus community. A culture of marketing has developed within the library (although not everyone is yet on board). The library is now included in most important discussions on campus, especially concerning the academic curriculum. Students, faculty, and administrators report that the library is the most vital entity on the campus. The library has become a magnet for campus initiatives as colleagues now look to us for leadership, support, and input. However, as we will no doubt continue to experience downturns in the economy, changes in the academic environment, and technological advances impacting the world of information, 
threats to the library budget will continue to be a reality. While the University Library at SSU has changed its image and the use of services and collections, it seems that not all support is tangible yet. Much remains philosophical-an important reason to continue marketing.

\section{WORKS CITED}

Brodsky, Karen. "Marketing Plan Jean and Charles Schulz Information Center, 1999." Internal Document.

Dodsworth, Ellen. "Marketing Academic Libraries: A Necessary Plan." The Journal of Academic Librarianship 24:4 (1998): 320-322.

Greenstein, Daniel and Leigh Watson Healy. "Print and Electronic Information: Shedding New Light on Campus Use." Educase Review September/October 2002: 16-17.

Hisle, W. Lee. "Top Issues Facing Academic Libraries." College \& Research Libraries News 63:10 (Nov 2002): 714-15, 730.

Jackson, Maureen. "Marketing the HyLiFe Project." Library Management 22:1/2 (2001): 43-49.

Levitt, Theodore. "Marketing Myopia." Harvard Business Review 75 (1975): 26-48.

Lipow, Anne Grodzins. "In Your Face Reference Service." Library Journal 124 (August 1999): 50-52.

Pew Research Center. The Internet Goes to College: How Students are Living in the Future with Today's Technology. September 15, $02<$ http://www.pewinternet.org/ reports>. 
Copyright of Reference Librarian is the property of Haworth Press and its content may not be copied or emailed to multiple sites or posted to a listserv without the copyright holder's express written permission. However, users may print, download, or email articles for individual use. 